\title{
Panel endorses price rise
}

\section{Washington}

A PANEL of eminent physicists, assembled by the Department of Energy (DoE) to defend its Superconducting Super Collider (SSC) from cutbacks, weighed in last week with a strongly worded opinion that the accelerator should be built despite cost overruns that could reach nearly $\$ 2,000$ million.

Although the panel's conclusions come as little surprise (see Nature 343, 103, 1990), DoE officials have indicated that they believe such an endorsement from a influential advisory body (including five Nobel laureates) is necessary ammunition for the approaching congressional battle over the 1991 budget. Congressional critics have been saying that cost overruns are likely ever since the project began four years ago.

The panel was unequivocal in its support of the machine at its full design energy of $20 \mathrm{TeV}$. Lowering the beam energy to 17 $\mathrm{TeV}$ would "yield an insufficient cost reduction to justify the reduction in physics", the panel's draft report says. Below $15 \mathrm{TeV}$, the SSC would "unacceptably ... risk missing important new physics". "The only way to keep the cost of the SSC at $\$ 5.9$ billion [DoE's original cost estimate] would be to seriously reduce its capabilities", the report continues. Asked to look for features that could be initially removed for substantial savings, but could then be restored later, the panel said that it found none. One reason for not cutting the SSC's energy is that one quickly reaches a point of diminishing returns, Columbia University Nobel prizewinner T. D. Lee told DoE's High Energy Physics Advisory Panel (HEPAP). He explained that when looking for particles such as the Higgs boson, the desired 'foreground' signal roughly doubles in strength between $15 \mathrm{TeV}$ and $20 \mathrm{TeV}$, while the background noise increases only lineariy. Although there would be some cost savings by shaving the SSC's energy, the chance of exploring new physics would decline precipitously, he said.

Senator Phil Gramm (Republican, Texas), an SSC supporter in whose state the accelerator would be built, warned HEPAP panel members that the project was facing resistance in Congress, and that austerity would be necessary. "We are in a position of trying to compete for resources with other projects that have large constituencies", he said. "It is important that we end up not with a Cadillac, but a sturdy Chevrolet." Although he emphasized that he could not predict how far the SSC's cost could escalate before it reached its "political threshold", he said he could "try to get Congress over the sticker shock".

G. Christopher Anderson FRENCH UNIVERSITIES

\section{Weapons clean up}

\section{Boston}

THE US Department of Energy announced last week that for the first time ever it would undertake sweeping environmental studies of its nuclear weapons production facilities. One of the 'programmatic environmental impact statements' will cover the department's plans to conduct a massive clean up of its existing facilities; another will review the agency's options in its efforts to modernize nuclear weapons production facilities.

The Energy Department's announcement came in the face of a lawsuit brought by eighteen environmental groups including the Natural Resources Defence Council. Although the Energy Department included no timetable or budget for the environmental reviews, it nonetheless marks a major step in opening up to greater public debate the potential environmental and health dangers from nuclear weapons production.

S.S.

\section{Out damned SPOT}

\section{Paris}

A LAST-Minute failure in one of the tape recorders on board the French Spot-2 commercial Earth observation satellite has set the launch back by several weeks. According to a French national space research centre (CNES) communiqué, the recorder did not rewind under remote control during a final check while the satellite was already aboard its Ariane launcher on the pad at Kourou, French Guyana.

The tape recorder is one of the two on board that temporarily store images while the satellite is out of range of ground receiving stations. Two similar tape recorders from the same manufacturer, the US company Odetics, were installed on Spot-1. One of these stopped working soon after the satellite was put into orbit, leaving a few permanent blind spots. But the surviving recorder has continued to function for the past four years - twice as long as planned.

Spot-2 has now been removed from the rocket's payload area so that the faulty component can be replaced - an operation which could take more than two weeks. P.C.

\section{Benveniste all-clear}

\section{Paris}

DR Jacques Benveniste, whose controversial work on the biological activity of highdilution solutions earned him a reprimand from the French medical and health research institute (INSERM) where he works, will be allowed to continue as head of his laboratory until 1992, when his present contract expires. When Benveniste's research was examined in a routine review last year, Phillipe Lazar, INSERM's director general, made the continuation of Benveniste's post contingent on 'good behaviour' - which meant keeping out of the press. 